[Letter]

\title{
Deoxygenation of Bio-oil over Reduced Catalysts
}

Takehisa MOCHIZUKI*, Makoto TOBA, and Yuji YOSHIMURA

National Institute of Advanced Industrial Science and Technology, Tsukuba, Ibaraki 305-8565, JAPAN

(Received March 8, 2011)

The upgrading of a fast pyrolysis bio-oil was studied with different catalysts in a small batch reactor. The catalysts were reduced $\mathrm{Ni} / \mathrm{SiO}_{2}, \mathrm{Co} / \mathrm{SiO}_{2}, \mathrm{Pt} / \mathrm{SiO}_{2}, \mathrm{Pd} / \mathrm{SiO}_{2}$ and sulfided $\mathrm{CoMo} / \mathrm{Al}_{2} \mathrm{O}_{3}$ catalysts. The experiments were carried out at $\mathrm{H}_{2}$ pressure 1-5 MPa, and temperature range of $300-350^{\circ} \mathrm{C}$. Reduced $\mathrm{Co} / \mathrm{SiO}_{2}$ catalyst showed the highest activity and highest aromatics selectivity for deoxygenation of guaiacol because this catalyst showed high activity for direct deoxygenation (DDO) of phenol giving mostly benzene.

\section{Keywords}

Deoxygenation, Bio-oil upgrading, Guaiacol, Cobalt silica catalyst, Jatropha husk, Biomass

\section{1. 緒 言}

輸送用燃料の石油依存度低減や地球環境保全の観点加 ら，再生可能資源であるバイオマス，特に食糧と競合しな い非食糧系バイオマスの輸送用然料化が期待されている。 ジャトロファは食糧系作物が適さない土地でも生育可能, 毒成分古含洔の理由から, 非食糧系バイオマスとして注 目されている。特にジャトロファ中に含まれる油脂類（約 $20 \mathrm{w} \%$ \%)はバイオブィーゼル然料として有用であり，既に 一部の地域で使用され始めている。しかし，約 $80 \mathrm{wt} \%$ 占める残渣の利用技術が確立しておらず, 残渣を有効利用 することができれば，より経済性を高めることができると 考壳られる。

ジャトロファ残渣中には, セルロース, ヘミセルロース, リグニンおよひ微量の油脂成分が含まれており，急速熱分 解により，リグニンから芳香族含酸素化合物，油脂から脂 肪酸に転換することが可能である。さらに，得られた芳香 族含酸素化合物や脂肪酸力ら脱酸素寸ることにより，ガソ リンの高オクタン価基材である芳香族炭化水素や軽油成 分へと転換することが可能である。

これまで，脱酸素触媒としては，脱硫触媒と同等の硫化 物触某が用いられる傾向にあるが，高い転化率を維持する ため，高温，高水素圧下で反応寸る必要があるい2。しか し, 芳香環の水素化によるオクタン価の低減や不飽和結合 への硫黄分の付加などが問題とされている。一方, 貴金属 触媒毛検討されているが，Pt の高担持(1 5 wt\%) 方必要と される ${ }^{34)}$ 。そこで本研究では，模擬バイオオイルとして グアイアコールおよび櫍系タールを用い，種々の還元触 媒を用いて脱酸素反応を行い，芳香環の水素化オクタン 価低減)最小限に抑え，脱酸素能方高い触媒の探索圭行 つた

\section{2. 実 験}

2.1. 触媒調製

遷移金属触媒は，い寸゙れも $\mathrm{SiO}_{2}$ (富士シリシア社製 Q-10) に硝酸塩水溶液を金属換算で $20 \mathrm{wt} \%$ となるよう incipient wetness 法により担持し, 一晚乾燥後, 空気中 $450^{\circ} \mathrm{Cで}$ 焼成 在行った。貴金属触媒は，金属換算で $1 \mathrm{wt} \%$ 担持し，以下 同様の手順を用いた。その後, 金属への還元が十分進行寸 るように, 水素中 $400^{\circ} \mathrm{C}, 2$ 時間還元して反応に使用した。 参照として $\mathrm{CoMo} / \mathrm{Al}_{2} \mathrm{O}_{3}$ を $360^{\circ} \mathrm{C} ， 2$ 時間硫化して用いた。

\section{2. 触媒活性評価}

活性試験は，模擬バイオオイルとして，グアイアコール $0.25 \mathrm{~g}+$ 溶媒(テトラデカン) $4.75 \mathrm{~g}$ ，もしくは木質系タール (C:69.2 wt \%, H:7.3 wt\%, O:23.3 wt\%, N:0.2 wt \%, S:50 ppm) $2.5 \mathrm{~g}$ 十溶媒(へキサデカン) $2.5 \mathrm{~g}$ 考用い，触媒 $0.25 \mathrm{~g}$ ，振動 型バッチ式オートクレーブにて，水素初期圧 5-7 MPa, $300-350^{\circ} \mathrm{C}, 1 \sim 3$ 時間, 脱酸素反店学行った。生成物の分 析にはGC-FID，GC-MS および元素分析を用いた。

\section{3. 結果と考察}

Table 1 に各種触某を用いたグアイアコールの脱酸素反 応結果䒚示寸。参照の硫化 $\mathrm{CoMo} / \mathrm{Al}_{2} \mathrm{O}_{3}$ は, 約 $78 \%$ の゙アア イアコール転化率を示寸吕，主生成物がフェノール(約 50\%)であり，次いでシクロへキサノン，シクロへキサノー ル,ベンゼンであり, 脱酸素率は著しく低かった。 $\mathrm{Ni} / \mathrm{SiO}_{2}$, $\mathrm{Co} / \mathrm{SiO}_{2}$ は $100 \%$ の転化率を示すが, $\mathrm{Ni} / \mathrm{SiO}_{2}$ ではシクロへ キサノールが主生成物であり，脱酸素率は低い。一方， $\mathrm{Co} / \mathrm{SiO}_{2}$ では, フェノールやシクロヘキサノールの生成は ほとんど見られず, ベンゼン，シクロへキサンが主に生成 し, 90\%以上の脱酸素率老示した。 $\mathrm{Pd} / \mathrm{SiO}_{2}$ は, $\mathrm{Ni} / \mathrm{SiO}_{2}$ と 同様な傾向を示寸が, 芳香環の水素化がさらに進行してお

“還元触媒によるバイオオイルの脱酸素反灾”

望月剛久*，鳥羽 誠，䔖村雄一

(独)産業技術総合研究所 新然料自動車技術研究センター，305-8565 茨城県つくば市東 1-1-1 つくば中央第 5 事業所

*連絡先, E-mail: t.mochizuki@aist.go.jp 
Table 1 Conversion and Yield for the Deoxygenation of Guaiacol over Several Catalysts

\begin{tabular}{lrrrrr}
\hline & $\mathrm{CoMo} / \mathrm{Al}_{2} \mathrm{O}_{3}$ & $\mathrm{Ni} / \mathrm{SiO}_{2}$ & $\mathrm{Co} / \mathrm{SiO}_{2}$ & $\mathrm{Pd} / \mathrm{SiO}_{2}$ & $\mathrm{Pt} / \mathrm{SiO}_{2}$ \\
\hline Conversion[\%] & 77.8 & 100 & 100 & 99.3 & 70.9 \\
Rate of deoxygenation[\%] & 18.4 & 43.6 & 92.8 & 59.3 & 55.6 \\
Yield[\%] & & & & & \\
$\quad$ Naphthene & 12.8 & 30.3 & 39.7 & 49.0 & 31.6 \\
Aromatics & 5.7 & 13.2 & 53.1 & 10.2 & 24.0 \\
Alcohol & 7.4 & 54.0 & 1.7 & 28.2 & 12.2 \\
Ketone & 2.3 & 1.5 & 4.7 & 9.6 & 0.8 \\
Phenol & 49.7 & 0.5 & 0.6 & 0.7 & 0.7 \\
Others & 0 & 0.3 & 0.2 & 0.9 & 1.6 \\
\hline
\end{tabular}

Reaction condition: Temperature $300^{\circ} \mathrm{C}$, Hydrogen pressure $1 \mathrm{MPa}$, Reaction time $1 \mathrm{~h}$.

り，シクロヘキサンが主生成物となった。また, $\mathrm{Pt} / \mathrm{SiO}_{2}$ は，転化率が約 $71 \%$ と今回用いた触媒の中で最も低いが， フェノールの生成はほとんど見られず, ベンゼンの生成は $\mathrm{Co} / \mathrm{SiO}_{2}$ に次いで高い以上の結果から，グアイアコール の脱酸素反応機構の概略を Scheme 1 に示す。いずれの触 媒を用いてもグアイアコールに対する反忘性は高く, ア二 ソールの生成もほとんど見られないため, 容易にフェノー ルが生成すると考えられる。一方， $\mathrm{Co} / \mathrm{SiO}_{2}$ では，シクロ ヘキサノンやシクロへキサノールの生成はほとんど見ら れず, 高い゙ンゼン選択率を示すことからフェノールから の直接脱酸素反応(DDO)によりベンゼンが生成している と考えられる。一方，他の触媒では，シクロヘキサノンも しくはシクロヘキサノールが多く生成していることから， フェノールの水素化反応(HYD)が主に進行していると考 えられる。ベンゼンを高選択的に得るためには，いずれの 触媒を用いてもフェノールに対する反応性が重要である ことが分かった。

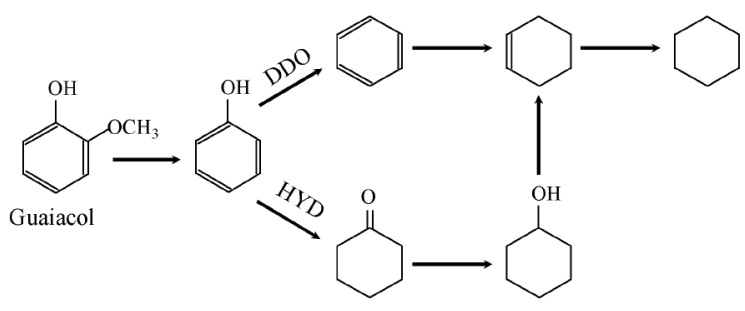

Scheme 1 Reaction Mechanism of Guaiacol Deoxygenation

Fig. 1 に木質系タールの脱酸素反応結果を示す。ここで 芳香族指標 (Index of aromatics) とは, ベンゼン, トルエン, エチルベンゼン, シクロヘキサン, メチルシクロへキサン, エチルシクロヘキサンの6種の化合物に占める, ベンゼン， トルエン，エチルベンゼンの割合を示している。硫化 $\mathrm{CoMo} / \mathrm{Al}_{2} \mathrm{O}_{3}$ 触媒の脱酸素率は約 $45 \%$ であり, 還元触媒 $\left(\mathrm{Pt} / \mathrm{SiO}_{2}\right.$ を除く)に比べて低く, 水素圧を $7 \mathrm{MPa}$ まで上昇さ せても脱酸素率は $51 \%$ とわずかに増加したのみであり, 芳 香族指標は著しく低下した。また，硫化 $\mathrm{CoMo} / \mathrm{Al}_{2} \mathrm{O}_{3}$ 触媒 を用いた場合のみ，反応生成物中の硫黄濃度が約 $120 \mathrm{ppm}$ と増加し，反応生成物中への硫黄分の付加が観察された。
一方，今回用いた触媒の中で $\mathrm{Ni} / \mathrm{SiO}_{2}$ が最も高い脱酸素率 を示すが, 芳香環が水素化され，芳香族指標が低い。また， $\mathrm{Co} / \mathrm{SiO}_{2}, \mathrm{Pd} / \mathrm{SiO}_{2}$ は，ほぼ同程度の脱酸素率を示すが， $\mathrm{Co} / \mathrm{SiO}_{2}$ が最も高い芳香族指標を示し，ガソリン留分の収 率も最も高い值を示した。

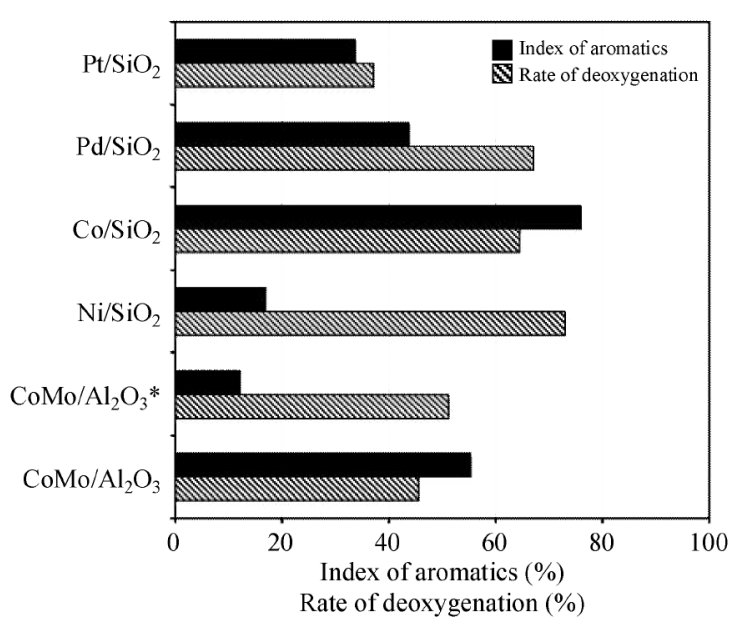

Reaction condition: Temperature $350^{\circ} \mathrm{C}$, Hydrogen pressure $5 \mathrm{MPa}$ (*7 MPa), Reaction time $3 \mathrm{~h}$.

Fig. 1 Deoxygenation of Woody Tar over Several Catalysts

\section{謝辞}

本研究はJST-JICA プロジェクト（地球規模課題対応国 際科学技術協力事業) 非食糧系バイオマスの輸送用然料化 基盤技術により行われた。ここに記して謝意を表す。

\section{References}

1) Bui, V.N., Laurenti, D., Afanasiev, P., Geantet, C., Appl. Catal. B: Environ., 101, 239(2011).

2) Donnis, B., Egeberg R.G., Blom, P., Knudsen, K.G., Top. Catal., 52, $229(2009)$.

3) Fisk, C.A., Morgan, T., Ji, Y., Crocker, M., Crofcheck, C., Lewis, S.A., Appl. Catal. A: Gen, 358, 150 (2009).

4) Mäki-Arvela, P., Kubickova, I., Snäre, M., Eränen, K., Murzin, D.Y., Energy \& Fuels, 21, 30 (2007). 